\title{
Comparison of Dried Plum Puree, Rosemary Extract, and BHA/BHT as Antioxidants in Irradiated Ground Beef Patties
}

\author{
Iulia Movileanu, ${ }^{1}$ Máryuri T. Núñez de González, ${ }^{2}$ Brian Hafley, ${ }^{3}$ \\ Rhonda K. Miller, ${ }^{4}$ and Jimmy T. Keeton ${ }^{5}$ \\ ${ }^{1}$ Department of Neurology, Upstate Medical University, 812 Jacobsen Hall, Syracuse, NY 13210, USA \\ ${ }^{2}$ Department of Food Technology, Universidad de Oriente, Núcleo Nueva Esparta, Escuela de Ciencias Aplicadas del Mar, \\ Isla de Margarita 6301, Venezuela \\ ${ }^{3}$ Tyson Foods, 1825 Ford Avenue, Springdale, AR 72764, USA \\ ${ }^{4}$ Department of Animal Science, Texas A\&M University, 338 Kleberg Center, College Station, TX 77843-2471, USA \\ ${ }^{5}$ Department of Nutrition and Food Science, Texas A\&M University, 122 Kleberg Center, College Station, TX 77843-2253, USA
}

Correspondence should be addressed to Jimmy T. Keeton; jkeeton@tamu.edu

Received 8 January 2013; Accepted 22 April 2013

Academic Editor: Alejandro Castillo

Copyright (C) 2013 Iulia Movileanu et al. This is an open access article distributed under the Creative Commons Attribution License, which permits unrestricted use, distribution, and reproduction in any medium, provided the original work is properly cited.

Fresh ground beef patties with (1) no antioxidant (control), (2) $0.02 \%$ butylated hydroxyanisole/butylated hydroxytoluene (BHA/BHT), (3) 3\% dried plum puree, or (4) $0.25 \%$ rosemary extract were aerobically packaged, irradiated at target doses of 0 , 1.5 , or $2.0 \mathrm{kGy}$ ( 1.7 and $2.3 \mathrm{kGy}$ actual doses), and stored at $4^{\circ} \mathrm{C}$. The samples were evaluated for lipid oxidation on $0,3,7,14$, 21 , and 28 days of storage after irradiation. When compared to the control, all antioxidant treatments were effective in retarding $(P<0.05)$ irradiation-induced lipid oxidation during storage as determined by 2 -thiobarbituric acid reactive substances (TBARs) values. Rosemary extracts had the same antioxidant effect $(P>0.05)$ as BHA/BHT in irradiated and nonirradiated beef patties, followed by the dried plum puree treatment. Irradiation increased TBARs values, but no differences were noted in oxidation between irradiation dose levels.

\section{Introduction}

Irradiation of refrigerated and frozen red meat and poultry has been approved by the Food and Drug Administration (FDA) [1] and the United States Department of AgricultureFood Safety and Inspection Service (USDA-FSIS) at levels up to $4.5-7.0 \mathrm{kGy}$ and $3.0 \mathrm{kGy}$, respectively, to effectively reduce or eliminate pathogenic bacteria [2]. Recently, the FDA approved a maximum absorbed dose of ionizing radiation of $4.5 \mathrm{kGy}$ to treat unrefrigerated (as well as refrigerated) uncooked meat, meat by-products, and certain meat food products to reduce levels of foodborne pathogens and extend shelf-life. Also, the regulation indicates that irradiation is a safe treatment for fresh (refrigerated and unrefrigerated) poultry food products and frozen poultry products at absorbed doses that do not exceed $4.5 \mathrm{kGy}$ and $7.0 \mathrm{kGy}$, respectively [3]. This technology can eliminate foodborne pathogenic microorganisms in meats and help provide a safer food supply for human consumption [4]. Populations of the most common enteric pathogens such as Escherichia coli O157:H7, Staphylococcus aureus, Salmonella, Listeria monocytogenes, and Aeromonas hydrophila can be significantly decreased or eliminated by low dose $(<3.0 \mathrm{kGy})$ treatments with ionizing radiation [5].

Use of irradiation on raw meat, however, results in the formation of radiolytic products [6] that can cause oxidation of myoglobin and lipids leading to discoloration, lipid oxidation, and formation of off-odor and off-flavor compounds $[7,8]$. Free radicals and hydroperoxides generated by irradiation can also destroy endogenous antioxidants, reduce storage stability, and increase off-flavors from lipid and protein degradation $[9,10]$. Although anaerobic packaging is an effective means of reducing oxidation, incorporation of antioxidants, synthetic or natural, is one of the major strategies for preventing lipid oxidation [11] and improving color stability of meat products. To be effective, antioxidants 
must compete with reactive meat components for free radicals generated by lipid oxidation and irradiation or inhibit the formation of free radicals induced by prooxidative metals $[12,13]$.

Rosemary (Rosmarinus officinalis) extracts have been found to be effective in inhibiting lipid oxidation in meat systems primarily through the presence of phenolic compounds $[14,15]$ which break free radical chain reactions by hydrogen atom donation [16]. Rosemary and rosemary extracts at concentrations ranging from $0.02 \%$ to $1 \%$ have been perhaps the most investigated natural antioxidants in meat products [17-21]. Various authors have reported the effectiveness of rosemary in ground beef [22], beef patties [23-26], pork patties [20, 27], pork sausage [28], and beef steaks [29].

Previous research has shown that dried plums have one of the highest antioxidant activities of both fruits and vegetables [30]. The principal phytochemicals in dried plums are phenolic compounds. These appear to be the primary contributors to antioxidant properties, are responsible for inhibition of low-density lipoprotein oxidation [31-33], and may play a role in suppressing cellular inflammation, a precursor to cancer development. The native antioxidant properties of dried plums may offer alternatives to the meat industry based on their potential to reduce microbial growth, retain moisture, and prevent off-flavor formation in meat [34].

The addition of $3 \%$ plum extract has been shown to improve mouthfeel and the antioxidant properties in irradiated turkey breast rolls [35]. Núñez de González et al. [36] demonstrated that dried plum puree at levels of $3 \%$ to $6 \%$ in precooked pork sausage was as effective as a butylated hydroxyanisole/butylated hydroxytoluene (BHA/BHT) combination in suppressing lipid oxidation. Moreover, Núñez de González et al. [37] reported that 2.5\% fresh juice concentrate or dried plum juice concentrate could be incorporated into beef roasts to reduce lipid oxidation and potentially warmedover flavor (WOF). Thus, the use of naturally occurring antioxidants (or extractives) with high antioxidant capacity may prove useful in retarding or reducing off-odors and offflavors in irradiated meat products and particularly ground beef patties which are more prone to lipid oxidation.

Synthetic antioxidants such as butylated hydroxyanisole (BHA) and butylated hydroxytoluene (BHT) have been widely used in meat products $[25,28,36,38]$. USDA regulations permit up to $0.01 \%$ (based on fat content) each of BHA and BHT in fresh sausage and up to $0.003 \%$ (based on total weight) each in dry sausage [39]. Addition of $0.02 \%$ BHA/BHT $(0.01 \%$ BHA $+0.01 \%$ BHT) in ground beef has been shown to be more effective in retarding lipid oxidation, as determined by lower levels of 2-thiobarbituric acid reactive substances (TBARs) [19], when compared to natural plant extracts. TBARs values for the treated samples did not change significantly during storage.

The objective of this study was to compare the antioxidant effectiveness of dried plum puree (3\%), BHA/BHT (0.02\%), and rosemary extract $(0.25 \%)$ in irradiated $(0,1.5$, or $2.0 \mathrm{kGy})$ ground beef patties stored refrigerated over a 28 -day period to assess their capacity in retarding lipid oxidation as measured by TBARs.

\section{Materials and Methods}

2.1. Beef Patty Preparation. Approximately $130 \mathrm{~kg}$ of fresh, coarse ground $(1.27-\mathrm{cm}$ plate) beef lean and fat trimmings were purchased from Ruffino Meats, Inc. (Bryan, TX), 3 to $4 \mathrm{~d}$ postmortem. Four $27.3 \mathrm{Kg}$ batches were formulated to contain $20 \%$ fat and assigned to treatments of no antioxidant (control), BHA/BHT $(0.02 \%$ combination based on the fat content, crystalline TENOX, Eastman Chemical Products, Kingsport, TN), rosemary extract $(0.25 \%$ based on batch weight, liquid oil based HERBALOX, Type HT 25, Kalsec, Inc., Kalamazoo, MI), and dried plum puree (3\% based on batch weight, Sunsweet Growers Inc., Yuba City, CA). No additional ingredients were included in the control treatment so that the true irradiation effect on $100 \%$ ground beef could be measured. The level of dried plum puree incorporated into ground beef patties was determined from a previous study in which 3\% was found to be effective in retarding lipid oxidation in precooked pork sausage [36]. Moreover, Lee and Ahn [35] indicated that the addition of 3\% plum extract was recommended to improve mouthfeel and antioxidant effect in irradiated turkey breast rolls.

Beef patties were manufactured in a state-inspected (Texas Department of Health) commercial-scale pilot plant located in the Rosenthal Meat Science and Technology Center at Texas A\&M University. Each coarse-ground treatment was blended in a paddle mixer (Model 150 767, Butcher Boy, Lasar, MFG Inc., Los Angeles, CA) for $3 \mathrm{~min}$ and reground through a 0.635-cm plate (Biro Model 1056 22772, The Biro Mfg Co., Marblehead, $\mathrm{OH}$ ). Dried plum puree, rosemary extract, and $\mathrm{BHA} / \mathrm{BHT}$ were incorporated directly into the mixer in their original commercial form. Patties $(113 \mathrm{~g}, 10.5 \mathrm{~cm}$ diameter, $1 \mathrm{~cm}$ thick) were made (Hollymatic JET FLOW Super Food Portioning Machine, 1033, Hollymatic Corp., Park Forest, IL) and stored at $-40^{\circ} \mathrm{C}$ for $2 \mathrm{~h}$. Approximately 220 patties per treatment were produced in this study. The crust frozen patties were then placed in Cryovac bags (Cryovac, Sealed Air Corporation, Duncan, SC) and aerobically packaged (a vacuum setting 3.5 on a 10 point scale where $10=$ maximum vacuum) to a constant level of air using an Ultravac packaging machine (Model 2100 D, KOCH Inc, Kansas City, MO). An aerobic package environment was chosen to exacerbate lipid oxidation and challenge the antioxidant treatments when exposed to a constant concentration of air and two electronbeam irradiation levels. Pulling a full vacuum (setting of 10) would have reduced irradiation mediated oxidation of each treatment and would have reduced the oxidative environment to stress each antioxidant's capacity for suppressing oxidation. After packaging, the patties were rapidly frozen $\left(-40^{\circ} \mathrm{C}\right)$ prior to shipping to an electron beam irradiation facility.

2.2. Irradiation of Samples and Storage. Frozen patties were placed in insulated containers with ice packs and shipped overnight to the Surebeam Corporation irradiation facility 
TABLE 1: Experimental design ${ }^{\mathrm{b}}$ of patty allocation by treatment and storage time.

\begin{tabular}{|c|c|c|c|c|c|c|c|c|}
\hline \multicolumn{2}{|c|}{ Treatment } & \multicolumn{7}{|c|}{ Storage time (day) } \\
\hline & Actual irradiation dose (kGy) & 0 & 3 & 7 & 14 & 21 & 28 & Total \\
\hline \multirow{3}{*}{ Control $^{\mathrm{a}}$} & 0 & 12 & 12 & 12 & 12 & 12 & 12 & 72 \\
\hline & 1.7 & 12 & 12 & 12 & 12 & 12 & 12 & 72 \\
\hline & 2.3 & 12 & 12 & 12 & 12 & 12 & 12 & 72 \\
\hline \multirow{3}{*}{$\mathrm{BHA} / \mathrm{BHT}^{\mathrm{a}}$} & 0 & 12 & 12 & 12 & 12 & 12 & 12 & 72 \\
\hline & 1.7 & 12 & 12 & 12 & 12 & 12 & 12 & 72 \\
\hline & 2.3 & 12 & 12 & 12 & 12 & 12 & 12 & 72 \\
\hline \multirow{3}{*}{ Dried plum puree ${ }^{a}$} & 0 & 12 & 12 & 12 & 12 & 12 & 12 & 72 \\
\hline & 1.7 & 12 & 12 & 12 & 12 & 12 & 12 & 72 \\
\hline & 2.3 & 12 & 12 & 12 & 12 & 12 & 12 & 72 \\
\hline \multirow{3}{*}{ Rosemary extract ${ }^{\mathrm{a}}$} & 0 & 12 & 12 & 12 & 12 & 12 & 12 & 72 \\
\hline & 1.7 & 12 & 12 & 12 & 12 & 12 & 12 & 72 \\
\hline & 2.3 & 12 & 12 & 12 & 12 & 12 & 12 & 72 \\
\hline Total & & & & & & & & 864 \\
\hline
\end{tabular}

(Glendale Heights, IL). Samples were tempered and irradiated at $-4^{\circ} \mathrm{C}$ at targeted doses of 0 (control), 1.5 , and $2 \mathrm{kGy}$ while passing through a linear accelerator. The targeted doses were determined based on previous studies [40, 41]. For each batch, a dosimetry profile was established for uniform packages of 12 patties stacked three high with an actual mean dose level of 1.7 and $2.3 \mathrm{kGy}$, respectively, for the irradiation treatments. To confirm the target dose, 2 alanine dosimeters per cart were attached to the top and bottom surface of a sample. All samples were hard frozen $\left(-20^{\circ} \mathrm{C}\right)$ after irradiation and returned via overnight carrier to the Department of Animal Science at Texas A\&M University. The patties remained in their original package as described above and were then stored and refrigerated at $4^{\circ} \mathrm{C}$ and evaluated on storage days $0,3,7,14,21$, and 28 . Day 0 was designated the next day after the return of the irradiated samples.

2.3. 2-Thiobarbituric Acid Reactive Substances (TBARs). Lipid oxidation of the ground beef patties from each treatment, irradiation level, and storage day was determined using the distillation 2-thiobarbituric acid (TBA) procedure of Tarladgis et al. [42], with the addition of propyl gallate and ethylenediaminetetraacetic acid (EDTA) at the sample blending step to prevent further lipid oxidation [43]. TBARs determinations were performed in duplicate, and results were expressed as mg of malonaldehyde per $\mathrm{kg}$ of meat sample. The percent reduction in TBARs by different treatments in comparison to control was also determined.

2.4. Experimental Design and Statistical Analysis. The experiment was designed as a factorial arrangement with a splitplot design. Batch treatments included (1) control (no antioxidant); (2) BHA/BHT; (3) dried plum puree, and (4) rosemary extract. The patties were aerobically packaged, irradiated at actual levels of $0,1.7$, and $2.3 \mathrm{kGy}$, and stored at $4^{\circ} \mathrm{C}$ for 0 ,
$3,7,14,21$, and 28 days. Seventy-two patties were randomly assigned to the batch treatment, dose level and storage condition (Table 1). One trial replication was processed to establish shipping requirements and analytical logistics followed by three complete experimental replications that were conducted individually approximately 6-7 weeks apart.

Analysis of variance was conducted using the General Linear Model (GLM) procedure of statistical analysis system [44]. Data was analyzed as a factorial arrangement with a split-plot design. The whole-plot included the main effects of batch and treatment. The error term for the whole plot was the batch by treatment interaction. The split-plot included the main effects of radiation dose and storage days and their interactions. The residual error was used to test split-plot effects at a significance value of $P<0.05$. Least square means were separated using the PDIFF statement of GLM [44]. Least square means were generated and reported for the main effects and for significant interactions.

\section{Results and Discussion}

TBARs values of beef patties containing different antioxidants and irradiated at two dose levels over 28 days at refrigerated conditions are presented in Tables 2 and 3. No differences in TBARs values $(P<0.05)$ were noted between doses 1.7 and $2.3 \mathrm{kGy}$, regardless of antioxidant treatment (Table 2). The inclusion of $\mathrm{BHA} / \mathrm{BHT}$ or rosemary extract retarded the oxidative process regardless of irradiation dose level, and TBARs values were lower than control patties not receiving irradiation. Lee et al. [38] found that thiobarbituric acid values were not very different during storage regardless of the irradiation dose or the type of antioxidant (rosemary extracts and BHA). In the present study, irradiated samples without antioxidants (control) had significantly higher TBARs values $(P<0.05)$ than the 1.7 and $2.3 \mathrm{kGy}$ irradiation levels with 
TABLE 2: Least square means for TBARs values of ground beef patties with/without antioxidants and irradiated at two dose levels.

\begin{tabular}{lcc}
\hline Treatment $^{\mathrm{d}}$ & Dose $^{\mathrm{e}}(\mathrm{kGy})$ & $\begin{array}{c}\text { TBARs } \\
\text { (mg malonaldehyde/kg sample) }\end{array}$ \\
Control & 0 & $1.56^{\mathrm{b}}$ \\
& 1.7 & $2.70^{\mathrm{c}}$ \\
& 2.3 & $2.68^{\mathrm{c}}$ \\
BHA/BHT & 0 & $0.42^{\mathrm{a}}$ \\
& 1.7 & $0.37^{\mathrm{a}}$ \\
& 2.3 & $0.52^{\mathrm{a}}$ \\
Dried plum & 0 & $0.43^{\mathrm{a}}$ \\
puree & 1.7 & $1.60^{\mathrm{b}}$ \\
& 2.3 & $1.61^{\mathrm{b}}$ \\
Rosemary & 0 & $0.57^{\mathrm{a}}$ \\
extract & 1.7 & $0.47^{\mathrm{a}}$ \\
RMS & 2.3 & $0.48^{\mathrm{a}}$ \\
\hline
\end{tabular}

${ }^{\mathrm{a}-\mathrm{c}}$ Least square means in the same column with superscripts that differ are significantly different $(P<0.05)$.

${ }^{\mathrm{d}}$ Control = no antioxidant; $\mathrm{BHA} / \mathrm{BHT}=$ butylated hydroxyanisole/butylated hydroxytoluene $(0.02 \%$ of fat content $)$; dried plum puree $=3.0 \%$ based on batch weight; rosemary extract $=0.25 \%$ based on batch weight.

${ }^{\mathrm{e}}$ Actual dosimetry levels were 1.7 and $2.3 \mathrm{kGy}$.

${ }^{\mathrm{f}} \mathrm{RMS}=$ root mean square error.

antioxidants (Table 2). Previous studies have indicated that irradiation accelerated lipid oxidation of raw meat under aerobic conditions $[13,40,45]$. Nawar [46] reported that irradiation in the presence of oxygen accelerated the autoxidation of fats by one of three possible reactions: (1) formation of free radicals which combine with oxygen to form hydroperoxides; (2) breakdown of hydroperoxides; and/or (3) destruction of antioxidants.

TBARs values showed that dried plum puree lessened the effect of irradiation-induced oxidation but also showed that it was less effective than BHA/BHT or rosemary treatments (Table 2). Overall, TBARs values were higher for dried plum puree than BHA/BHT or rosemary extract, even though dried plum puree partially reduced the oxidative effects of irradiation. It is postulated that the antioxidant component(s) in 3\% dried plum puree might not be as concentrated as that found in the rosemary extract or BHA/BHT. Thus, equivalent levels of the antioxidant components in dried plum puree need to be identified and characterized prior to additional comparisons. The protective antioxidant effect of BHA/BHT and rosemary extract was not altered by irradiation dose. However, it cannot be ruled out that oxidation might occur in beef patties treated with higher levels of irradiation. In conclusion, rosemary extract and $\mathrm{BHA} / \mathrm{BHT}$ treatments maintained lower and equivalent TBARs values regardless of dose level (1.7 or $2.3 \mathrm{kGy}$ ), while dried plum puree patties had slightly higher TBARs values. These values, however, were still significantly lower $(P<0.05)$ than the irradiated control.
TABLE 3: Least square means for TBARS values of irradiated ground beef patties treated with/without antioxidants and stored at $4^{\circ} \mathrm{C}$ for 28 days.

\begin{tabular}{|c|c|c|}
\hline Treatment $^{\mathrm{h}}$ & Storage day & $\begin{array}{c}\text { TBARS } \\
\text { (mg malonaldehyde/kg sample) }\end{array}$ \\
\hline \multirow{6}{*}{ Control } & 0 & $0.97^{\mathrm{bcd}}$ \\
\hline & 3 & $1.97^{\mathrm{e}}$ \\
\hline & 7 & $2.52^{\mathrm{f}}$ \\
\hline & 14 & $2.79^{\mathrm{fg}}$ \\
\hline & 21 & $2.58^{\mathrm{fg}}$ \\
\hline & 28 & $3.04^{\mathrm{g}}$ \\
\hline \multirow{6}{*}{$\mathrm{BHA} / \mathrm{BHT}$} & 0 & $0.30^{\mathrm{a}}$ \\
\hline & 3 & $0.32^{\mathrm{a}}$ \\
\hline & 7 & $0.36^{\mathrm{a}}$ \\
\hline & 14 & $0.44^{\mathrm{a}}$ \\
\hline & 21 & $0.74^{\mathrm{abc}}$ \\
\hline & 28 & $0.46^{\mathrm{ab}}$ \\
\hline \multirow{6}{*}{$\begin{array}{l}\text { Dried plum } \\
\text { puree }\end{array}$} & 0 & $0.51^{\mathrm{ab}}$ \\
\hline & 3 & $0.83^{\mathrm{abc}}$ \\
\hline & 7 & $1.02^{\mathrm{cd}}$ \\
\hline & 14 & $1.56^{\mathrm{e}}$ \\
\hline & 21 & $1.89^{\mathrm{e}}$ \\
\hline & 28 & $1.46^{\mathrm{de}}$ \\
\hline \multirow{6}{*}{$\begin{array}{l}\text { Rosemary } \\
\text { extract }\end{array}$} & 0 & $0.32^{\mathrm{a}}$ \\
\hline & 3 & $0.39^{\mathrm{a}}$ \\
\hline & 7 & $0.44^{\mathrm{a}}$ \\
\hline & 14 & $0.54^{\mathrm{abc}}$ \\
\hline & 21 & $0.53^{\mathrm{abc}}$ \\
\hline & 28 & $0.83^{\mathrm{abc}}$ \\
\hline $\mathrm{RMS}^{\mathrm{i}}$ & & 0.55 \\
\hline
\end{tabular}

${ }^{\mathrm{a}-\mathrm{g}}$ Least square means in the same column with superscripts that differ are significantly different $(P<0.05)$.

${ }^{\mathrm{h}}$ Control = no antioxidant; $\mathrm{BHA} / \mathrm{BHT}=$ butylated hydroxyanisole/butylated hydroxytoluene $(0.02 \%$ of fat content); dried plum puree $=3.0 \%$ based on batch weight; rosemary extract $=0.25 \%$ based on batch weight.

${ }^{\mathrm{i}} \mathrm{RMS}=$ root mean square error.

All antioxidant treatments reduced TBARs values of all irradiated samples during the storage period when compared to the control (Table 3). Lipid oxidation, as measured by TBARs, of the control treatment increased significantly $(P<$ 0.05 ) through day 7 , remained static to day 21 , and increased slightly from day 21 to day 28. Among the antioxidant treatments, samples containing BHA/BHT and rosemary extract showed the greatest antioxidant effect. There was an increase in TBARs values over time for the dried plum puree, but not to the same degree as the control. This increase was likely due to the inability of the dried plum puree's antioxidant component to completely suppress the oxidative effect of irradiation. Although, BHA/BHT and rosemary extract TBARs values increased slightly numerically, they were not statistically $(P>0.05)$ significant within a treatment over the storage period. When compared to the control, BHA/BHT and rosemary reduced TBARs by 69 and 67\%, respectively, 
TABLE 4: Percent decrease in TBARs values for irradiated ground beef patties treated with/without antioxidants and stored at $4^{\circ} \mathrm{C}$ for 28 days.

\begin{tabular}{|c|c|c|c|c|c|c|}
\hline \multirow{3}{*}{ Treatment $^{\mathrm{b}}$} & \multicolumn{6}{|c|}{ Percent decrease in TBARs as compared to control ${ }^{\mathrm{a}}$} \\
\hline & \multicolumn{6}{|c|}{ Storage day } \\
\hline & 0 & 3 & 7 & 14 & 21 & 28 \\
\hline $\mathrm{BHA} / \mathrm{BHT}$ & 69.1 & 83.8 & 85.7 & 84.2 & 71.3 & 84.9 \\
\hline Rosemary extract & 67.0 & 80.2 & 82.5 & 80.6 & 79.4 & 72.7 \\
\hline Dried plum puree & 47.4 & 57.9 & 59.5 & 44.0 & 26.7 & 52.0 \\
\hline
\end{tabular}

at day 0 (Table 4) and continued to have consistently high antioxidant activity throughout the 28-day storage period. Nam and Ahn [13] compared the TBARs values of irradiated pork homogenates containing sesamol $(200 \mu \mathrm{M})$ and Trolox $(200 \mu \mathrm{M})$ and found them to reduce TBARs values by as much as $72 \%$ when compared to other antioxidants after 5 days of storage. Nam et al. [12] indicated that irradiated pork loins treated with rosemary-tocopherol/double packaging had lower TBARs values than a vacuum-packaged control after 10 days of refrigerated storage. Rosemary oleoresin (200 ppm based on fat content) in pork patties, irradiated at $4.5 \mathrm{kGy}$ and stored at $4^{\circ} \mathrm{C}$ for 7 days, was shown to be effective only for the first 3 days of the storage period [9], while BHT $(0.01 \%)$ was effective across all storage days.

In this study, BHA/BHT and rosemary TBARs values did not differ $(P>0.05)$ from one another during storage of irradiated beef patties. Similarly, rosemary extract was noted to be equally effective as $\mathrm{BHA} / \mathrm{BHT}$ in maintaining low TBARs values of nonirradiated refrigerated, fresh pork sausage and cooked-frozen sausage [28]. McBride et al. [25] indicated that rosemary extract was more effective in controlling lipid oxidation in aerobically stored beef samples as compared with a control or a BHA/BHT treatment. Additional antioxidant effects of rosemary in meats and meat products have been reported extensively in the scientific literature [20, 22-24, 26, 29].

Dried plum puree was not as effective as rosemary extract or BHA/BHT (Tables 3 and 4) in inhibiting oxidation over the storage period but did reduce $(P<0.05)$ TBARs values by approximately $50 \%$ when compared to the control. At day 0 (Table 4), dried plum puree decreased TBARs values by $47.4 \%$ but was less effective as an antioxidant from day 14 to 21 . Lee and Ahn [35] likewise reported that the addition of $2 \%$ or $3 \%$ of plum extract puree was effective in controlling lipid oxidation in irradiated turkey breast rolls.

Dried plum puree contains numerous components such as dextrose, sorbitol, and other compounds that could dilute and lessen its antioxidant effectiveness. Based on this observation, further work is needed to extract, identify, and standardize the principle antioxidant components of dried plum puree and then test their efficacy. Thus, a dried plum puree extract could potentially have the same or possibly greater antioxidant capacity as that of rosemary extract or a $\mathrm{BHA} / \mathrm{BHT}$ combination in irradiated ground beef patties.

\section{Conclusions}

All antioxidant treatments decreased TBARs values in ground beef patties irradiated at 1.7 and $2.3 \mathrm{kGy}$. Rosemary $(0.25 \%)$ and BHA/BHT $(0.02 \%)$ were the most effective antioxidants, while dried plum puree (3\%) also reduced lipid oxidation but to a lesser degree. Irradiation doses of 1.7 and $2.3 \mathrm{kGy}$ increased TBARs values, but no differences in oxidation were noted between irradiation dose levels.

\section{Acknowledgment}

This project was funded by Texas A\&M AgriLife Research, an agency of the Texas A\&M University System.

\section{References}

[1] CFR Code of Federal Regulations, Ionizing Radiation for the Treatment of Food. Title 21, Part 179.26, Government Printing Office, Washington, DC, USA, 2001.

[2] D. G. Olson, "Meat irradiation and meat safety", in Proceedings of the 51st Reciprocal Meat Conference, pp. 149-152, Storrs, CT, USA, June-July 1998.

[3] FDA, "Irradiation in the production, processing and handling of food," Federal Register, vol. 77, no. 231, pp. 71312-71321, 2012.

[4] Y. Liu, X. Fan, Y. R. Chen, and D. W. Thayer, "Changes in structure and color characteristics of irradiated chicken breasts as a function of dosage and storage time," Meat Science, vol. 63, no. 3, pp. 301-307, 2003.

[5] D. W. Thayer, "Use of irradiation to kill enteric pathogens on meat and poultry," Journal of Food Safety, vol. 15, pp. 181-192, 1995.

[6] R. J. Woods and A. K. Pikaev, "Interaction of radiation with matter," in Applied Radiation Chemistry: Radiation Processing, pp. 59-89, John Wiley \& Sons, New York, NY, USA, 1994.

[7] E. A. Murano, "Irradiation of fresh meats," Food Technology, vol. 49, no. 12, pp. 52-54, 1995.

[8] K. E. Nanke, J. G. Sebranek, and D. G. Olson, "Color characteristics of irradiated vacuum-packaged pork, beef, Turkey," Journal of Food Science, vol. 63, no. 6, pp. 1001-1006, 1998.

[9] X. Chen, C. Jo, J. I. Lee, and D. U. Ahn, "Lipid oxidation, volatiles and color changes of irradiated pork patties as affected by antioxidants," Journal of Food Science, vol. 64, no. 1, pp. 16-19, 1999. 
[10] C. Jo and D. U. Ahn, "Volatiles and oxidative changes in irradiated pork sausage with different fatty acid composition and tocopherol content," Journal of Food Science, vol. 65, no. 2, pp. 270-275, 2000.

[11] M. C. Rojas and M. S. Brewer, "Effect of natural antioxidants on oxidative stability of cooked, refrigerated beef and pork," Journal of Food Science, vol. 72, no. 4, pp. S282-S288, 2007.

[12] K. C. Nam, K. Y. Ko, B. R. Min et al., "Influence of rosemarytocopherol/packaging combination on meat quality and the survival of pathogens in restructured irradiated pork loins," Meat Science, vol. 74, no. 2, pp. 380-387, 2006.

[13] K. C. Nam and D. U. Ahn, "Use of antioxidants to reduce lipid oxidation and off-odor volatiles of irradiated pork homogenates and patties," Meat Science, vol. 63, no. 1, pp. 1-8, 2003.

[14] C. M. Houlihan, C. T. Ho, and S. S. Chang, "Elucidation of the chemical structure of a novel antioxidant, rosmaridiphenol, isolated from rosemary," Journal of the American Oil Chemists' Society, vol. 61, no. 6, pp. 1036-1039, 1984.

[15] W. Zheng and S. Y. Wang, "Antioxidant activity and phenolic compounds in selected herbs," Journal of Agricultural and Food Chemistry, vol. 49, no. 11, pp. 5165-5170, 2001.

[16] H. Basaga, C. Tekkaya, and F. Acikel, "Antioxidative and free radical scavenging properties of rosemary extract," $L W T$ - Food Science and Technology, vol. 30, no. 1, pp. 105-108, 1997.

[17] A. J. St. Angelo, K. L. Crippin, H. P. Dupuy, and C. James Jr., "Chemical and sensory studies of antioxidant-treated beef," Journal of Food Science, vol. 55, no. 6, pp. 1501-1505, 1990.

[18] T. L. McCarthy, J. P. Kerry, J. F. Kerry, P. B. Lynch, and D. J. Buckley, "Evaluation of the antioxidant potential of natural food/plant extracts as compared with synthetic antioxidants and vitamin e in raw and cooked pork patties," Meat Science, vol. 58, no. 1, pp. 45-52, 2001.

[19] J. Ahn, I. U. Grün, and L. N. Fernando, "Antioxidant properties of natural plant extracts containing polyphenolic compounds in cooked ground beef," Journal of Food Science, vol. 67, no. 4, pp. 1364-1369, 2002.

[20] L. R. Nissen, D. V. Byrne, G. Bertelsen, and L. H. Skibsted, "The antioxidative activity of plant extracts in cooked pork patties as evaluated by descriptive sensory profiling and chemical analysis," Meat Science, vol. 68, no. 3, pp. 485-495, 2004.

[21] J. Han and K. S. Rhee, "Antioxidant properties of selected Oriental non-culinary/nutraceutical herb extracts as evaluated in raw and cooked meat," Meat Science, vol. 70, no. 1, pp. 25-33, 2005.

[22] C. W. Balentine, P. G. Crandall, C. A. O’Bryan, D. Q. Duong, and F. W. Pohlman, "The pre- and post-grinding application of rosemary and its effects on lipid oxidation and color during storage of ground beef," Meat Science, vol. 73, no. 3, pp. 413-421, 2006.

[23] A. Sánchez-Escalante, D. Djenane, G. Torescano, J. A. Beltrán, and P. Roncalés, "Antioxidant action of borage, rosemary, oregano, and ascorbic acid in beef patties packaged in modified atmosphere," Journal of Food Science, vol. 68, no. 1, pp. 330-344, 2003.

[24] A. Sánchez-Escalante, D. Djenane, G. Torrescano, J. A. Beltrán, and P. Roncalés, "The effects of ascorbic acid, taurine, carnosine and rosemary powder on colour and lipid stability of beef patties packaged in modified atmosphere," Meat Science, vol. 58, no. 4, pp. 421-429, 2001.

[25] N. T. M. McBride, S. A. Hogan, and J. P. Kerry, "Comparative addition of rosemary extract and additives on sensory and antioxidant properties of retail packaged beef,' International Journal of Food Science and Technology, vol. 42, no. 10, pp. 12011207, 2007.

[26] M. N. Lund, M. S. Hviid, and L. H. Skibsted, "The combined effect of antioxidants and modified atmosphere packaging on protein and lipid oxidation in beef patties during chill storage," Meat Science, vol. 76, no. 2, pp. 226-233, 2007.

[27] K. C. Nam, K. Y. Ko, B. R. Min et al., "Effects of oleoresintocopherol combinations on lipid oxidation, off-odor, and color of irradiated raw and cooked pork patties," Meat Science, vol. 75, no. 1, pp. 61-70, 2007.

[28] J. G. Sebranek, V. J. H. Sewalt, K. L. Robbins, and T. A. Houser, "Comparison of a natural rosemary extract and BHA/BHT for relative antioxidant effectiveness in pork sausage," Meat Science, vol. 69, no. 2, pp. 289-296, 2005.

[29] D. Djenane, A. Sánchez-Escalante, J. A. Beltrán, and P. Roncalés, "Ability of a-tocopherol, taurine and rosemary, in combination with vitamin $\mathrm{C}$, to increase the oxidative stability of beef steaks packaged in modified atmosphere," Food Chemistry, vol. 76, no. 4, pp. 407-415, 2002.

[30] H. Wang, G. Cao, and R. L. Prior, "Total antioxidant capacity of fruits," Journal of Agricultural and Food Chemistry, vol. 44, no. 3, pp. 701-705, 1996.

[31] M. Stacewicz-Sapuntzakis, P. E. Bowen, E. A. Hussain, B. I. Damayanti-Wood, and N. R. Farnsworth, "Chemical composition and potential health effects of prunes: a functional food?" Critical Reviews in Food Science and Nutrition, vol. 41, no. 4, pp. 251-286, 2001.

[32] J. L. Donovan, A. S. Meyer, and A. L. Waterhouse, "Phenolic composition and antioxidant activity of prunes and prune juice (Prunus domestica)," Journal of Agricultural and Food Chemistry, vol. 46, no. 4, pp. 1247-1252, 1998.

[33] S. E. Kasim-Karakas, R. U. Almario, L. Gregory, H. Todd, R. Wong, and B. L. Lasley, "Effects of prune consumption on the ratio of 2-hydroxyestrone to $16 \alpha$-hydroxyestrone," American Journal of Clinical Nutrition, vol. 76, no. 6, pp. 1422-1427, 2002.

[34] H. Kreuzer, Dried Plums Solve Meaty Issues. Food Product Design, Weeks Publishing, Northbrook, Ill, USA, 2001.

[35] E. J. Lee and D. U. Ahn, "Quality characteristics of irradiated turkey breast rolls formulated with plum extract," Meat Science, vol. 71, no. 2, pp. 300-305, 2005.

[36] M. T. Núñez de González, R. M. Boleman, R. K. Miller, J. T. Keeton, and K. S. Rhee, "Antioxidant properties of dried plum ingredients in raw and precooked pork sausage," Journal of Food Science, vol. 73, no. 5, pp. H63-H71, 2008.

[37] M. T. Núñez de González, B. S. Hafley, R. M. Boleman, R. K. Miller, K. S. Rhee, and J. T. Keeton, "Antioxidant properties of plum concentrates and powder in precooked roast beef to reduce lipid oxidation," Meat Science, vol. 80, no. 4, pp. 9971004, 2008.

[38] J. W. Lee, K. S. Park, J. G. Kim et al., “Combined effects of gamma irradiation and rosemary extract on the shelf-life of a ready-toeat hamburger steak," Radiation Physics and Chemistry, vol. 72, no. 1, pp. 49-56, 2005.

[39] CFR Code of Federal Regulations, Food Ingredients and Sources of Irradiation. Title 9, Part 424, Subpart C, Government Printing Office, Washington, DC, USA, 2009, http://www.ecfr.gov/cgi-bin/text-idx?c=ecfr\&sid=ff85ab30d9f $72231 \mathrm{cf} 408 \mathrm{cf} 2293 \mathrm{e} 83 \mathrm{da} \& \mathrm{rgn}=\operatorname{div} 8 \& \mathrm{view}=$ text $\&$ node $=9: 2.0 .2 .4$ .41 .2 .70 .18 idno $=9$. 
[40] S. E. Luchsinger, D. H. Kropf, C. M. García Zepeda et al., "Color and oxidative properties of irradiated ground beef patties," Journal of Muscle Foods, vol. 8, no. 4, pp. 445-464, 1997.

[41] K. E. Nanke, J. G. Sebranek, and D. G. Olson, "Color characteristics of irradiated aerobically packaged pork, beef, and turkey," Journal of Food Science, vol. 64, no. 2, pp. 272-278, 1999.

[42] B. G. Tarladgis, B. M. Watts, M. T. Younathan, and L. Dugan, "A distillation method for the quantitative determination of malonaldehyde in rancid foods," Journal of the American Oil Chemists' Society, vol. 37, no. 1, pp. 44-48, 1960.

[43] K. S. Rhee, "Minimization of further lipid peroxidation in the distillation 2-thibarbituric acid test of fish and meat," Journal of Food Science, vol. 43, no. 6, pp. 1776-1778, 1978.

[44] SAS, SAS USer's Guide, Statistical Analysis System Institute, Cary, NC, USA, 1995.

[45] Y. H. Kim, K. C. Nam, and D. U. Ahn, "Volatile profiles, lipid oxidation and sensory characteristics of irradiated meat from different animal species," Meat Science, vol. 61, no. 3, pp. 257$265,2002$.

[46] W. W. Nawar, "Lipids," in Food Chemistry, O. Fennema, Ed., pp. 139-244, Marcel Dekker, Inc., New York, NY, USA, 1985. 

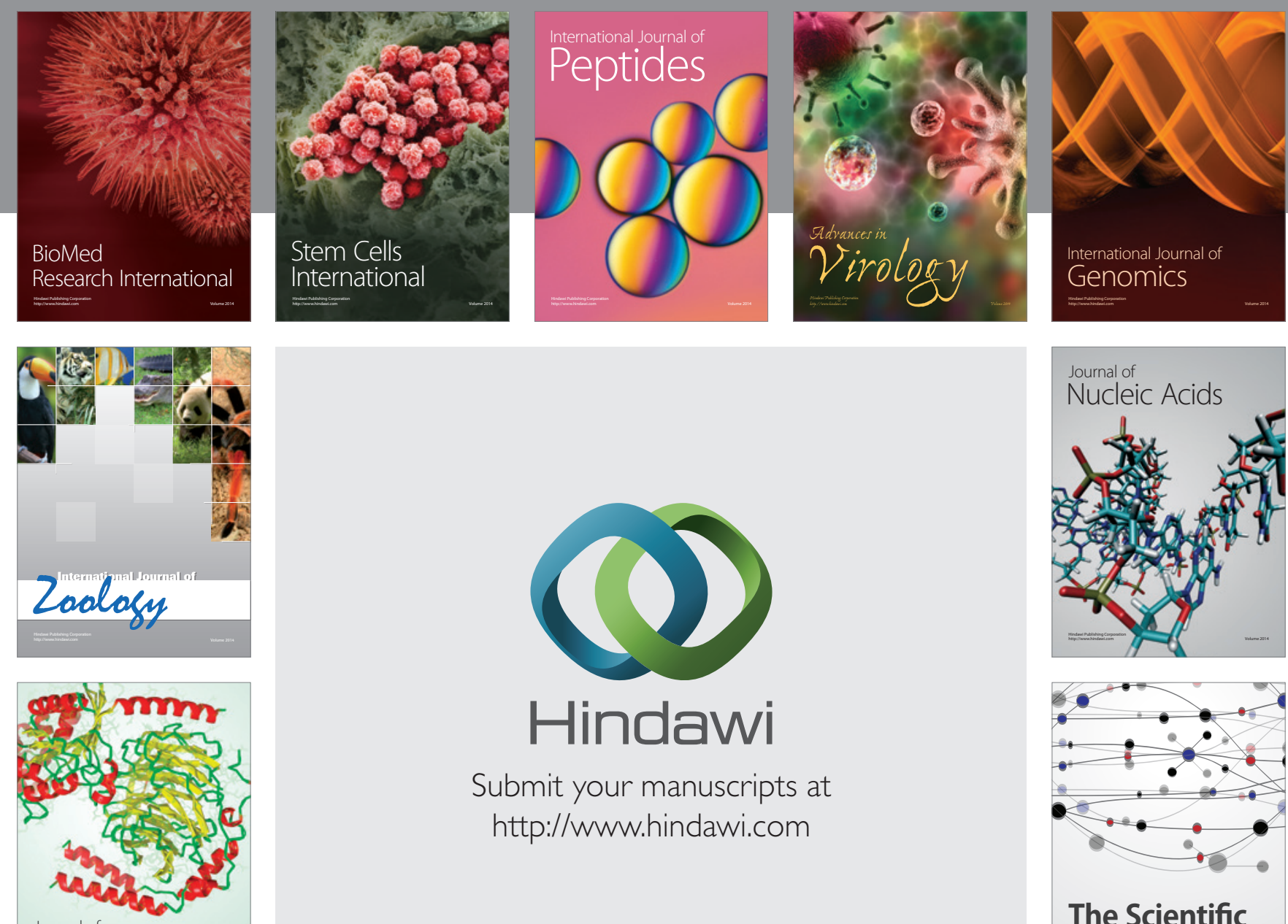

Submit your manuscripts at

http://www.hindawi.com

Journal of
Signal Transduction
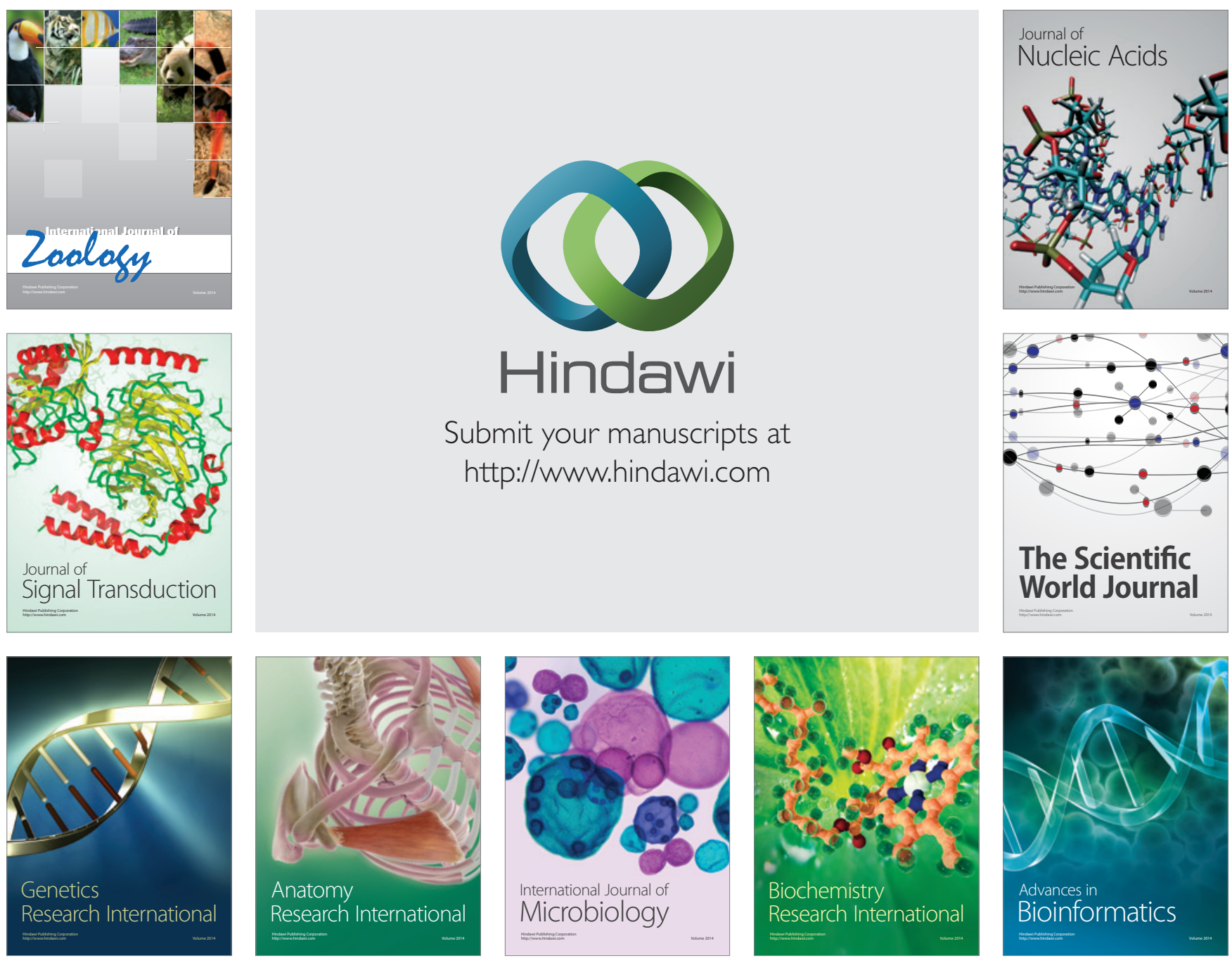

The Scientific World Journal
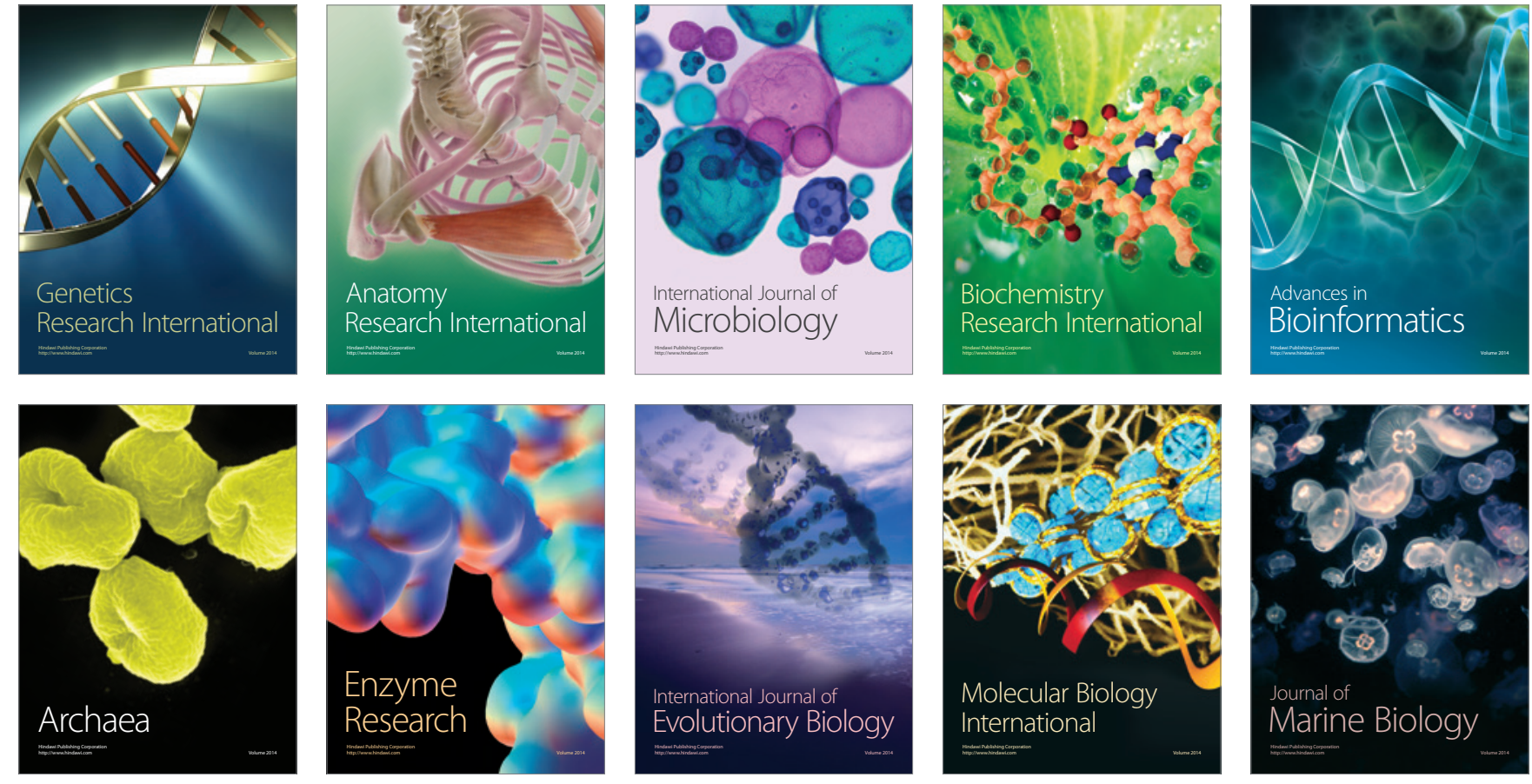